\title{
Expression of prolactin gene in incubating hens
}

\author{
K. Shimada, H. Ishida, K. Sato, H. Seo* and N. Matsui* \\ Department of Animal Physiology, Faculty of Agriculture, Nagoya University, Chikusa, \\ Nagoya 464-01 Japan; and *Research Institute of Environmental Medicine, Nagoya University, \\ Nagoya 464-01, Japan
}

\begin{abstract}
Summary. Steady-state levels of the $1 \cdot 38-\mathrm{kb}$ mRNA encoding the prolactin prohormone, measured by northern and dot blotting using a radioactive cDNA probe, rose 10 -fold with concomitant increases in concentrations of prolactin in anterior pituitary and plasma from non-incubating to incubating stages in Gifujidori bantam hens. Daily injections of a low dose of thyrotrophin-releasing hormone (TRH, $0 \cdot 25 \mu \mathrm{g} / \mathrm{kg}$ ) for 4 days caused no changes in the concentrations of prolactin of the mRNA, but a high dose $(2.5 \mu \mathrm{g} / \mathrm{kg})$ of TRH did induce a significant increase in prolactin mRNA levels compared to saline controls. The results suggest that gene expression for prolactin increases substantially during the incubation period and TRH may contribute, at least in part, to the increase in transcription of prolactin mRNA for prolactin biosynthesis in Gifujidori bantam hens.
\end{abstract}

Keywords: gene expression; prolactin mRNA; northern hybridization; incubating hen; TRH

\section{Introduction}

Prolactin has been implicated in the regulation of broodiness in birds since Riddle et al. (1935) first demonstrated that injections of prolactin induce incubation behaviour. Subsequent studies with chickens and turkeys showed that the start of egg incubation is associated with a marked increase in circulating prolactin concentrations which are maintained throughout the incubation period, and, with the termination of incubation and the hatch of chicks, concentrations decline to a low value (Sharp et al., 1979, 1988; Burke \& Dennison, 1980; Harvey et al., 1981; Proudman \& Opel, 1981; Zadworny et al., 1985, 1988). The increased pituitary content of prolactin during the incubation period (Saeki \& Tanabe, 1955; Cherms et al., 1962; Burke \& Pupkoff, 1980) suggests that an increased rate of prolactin synthesis may occur which in turn sustains the high concentrations of prolactin observed in the circulating blood throughout the incubation period. However, few studies have been conducted concerning biosynthesis of prolactin or its regulation in birds with more direct indices. In mammals, it is well known that prolactin biosynthesis is stimulated via gene expression (i.e. transcriptional processing) for prolactin by thyrotrophin-releasing hormone (TRH, Murdoch et al., 1985; Laveriere et al., 1988) and oestradiol (Maurer, 1982; Yamamoto et al., 1986; Seo, 1989). Although the transcriptional regulation for prolactin is not fully understood, TRH may be involved in gene expression via an increase in protein kinase $C$ activity (Murdoch et al., 1985) and calcium efflux (Laveriere et al., 1988), while oestradiol may be involved by binding its receptor which in turn initiates transcription by binding the $5^{\prime}$ flanking region of the prolactin gene in mammalian pituitary cells. As far as we are aware, little is known about the transcription mechanism for the prolactin gene in birds.

The mRNA encoding prolactin in the anterior pituitary of the chicken has been cloned as cDNA by Hanks et al. (1989) and Watahiki et al. (1989). Sequence determination reveals that prohormone prolactin consists of 30 amino acids as a signal peptide and 199 amino acids of mature prolactin. Although there are 3 different amino acids between sequences of the mature prolactin 
deduced by the two groups, it may not be a large discrepancy unless both proteins possess different biological activities. Hence, utilization of the cDNA for prolactin as a probe to quantitate prolactin mRNA should provide a new insight to investigate the molecular basis for gene expression for prolactin biosynthesis as well as evolutionary aspects of prolactin molecules in birds. Accordingly, this study was conducted to elucidate changes in expression of the prolactin gene in relation to incubation and the effect of TRH on prolactin transcription in Gifujidori hens which have been reported to exhibit broody behaviour (Kono et al., 1985; Zadworny et al., 1989).

\section{Materials and Methods}

Animals and collections of tissue and plasma samples. Gifujidori hens (a strain of Japanese bantams) weighing 650$800 \mathrm{~g}$ were housed in deep-litter floor pens containing nest boxes under natural daylight until the experiments were initiated at Nagoya University in mid-October. Food and water were available ad libitum. All hens had ceased egg production but showed no visible signs of moult, i.e. they were out-of-lay (Zadworny et al., 1989). The hens were then exposed to $4 \mathrm{~h}$ of artificial illumination in addition to natural daylight (a total of 15 h illumination; 04:00-19:00 h) until the end of the experiments.

In Exp. I, 5 hens were randomly selected and killed for collection of blood and tissue samples before addition of artificial lighting (pre-photostimulation group). At 26 days after additional illumination 5 hens were killed and blood and tissue samples were collected. The other hens were allowed to lay and accumulate clutches of eggs; those which began to incubate and had been sitting on their eggs for about 7 days were selected as incubating hens and the samples were collected.

For Exp. II, at 2 weeks after starting the 4-h artificial illumination, in addition to natural daylight, hens were randomly divided into 3 groups. Each group was assigned daily injections of saline $(1 \cdot 0 \mathrm{ml} / \mathrm{hen})$ or TRH in saline $(0.25$ or $2.5 \mu \mathrm{g} / \mathrm{kg}$, Sigma, St Louis, MO, USA) at $10: 00 \mathrm{~h}$ for 4 days, respectively. The doses of the hormone were adopted from previous studies (Harvey et al., 1978; Fehrer et al., 1985). At the end of the experiment, hens were lightly anaesthetized by pentobarbital injection, and trunk blood was collected from the carotid artery into heparinized test tubes. Plasma was separated by centrifugation and stored at $-20^{\circ} \mathrm{C}$ until required for assay. Anterior pituitary glands were removed immediately after decapitation, placed in sterile microfuge tubes, snap-frozen in liquid nitrogen, and stored at $-80^{\circ} \mathrm{C}$.

RNA extraction. Total RNA was prepared from individual pituitaries. Each pituitary gland was homogenized in $100 \mu 10.5 \%$ Nonidet P40 (Sigma), $10 \mathrm{~mm}$-Tris-HCl, 1 mm-ethyldiaminotetracetic acid (EDTA). A portion (5 $\mu \mathrm{l}$ ) of the homogenate was used for radioimmunoassay (RIA) for prolactin and the remaining homogenate for the extraction of the total RNA according to the procedures described by Chomczynski \& Sacchi (1987). The amount of total RNA was estimated by spectrophotometry.

${ }^{32} P$-labelled chicken prolactin cDNA probe. The probe for northern and dot-blot hybridization was a purified SspI$\mathrm{XbaI}$ restricted fragment ( 270 base pairs) of chicken prolactin cDNA (generously provided by $\operatorname{Dr} \mathrm{K}$. Nakashima, Mie University, Japan), labelled with deoxycytidine 5 -triphosphate $\left({ }^{32} \mathrm{P}\right.$-dCTP; $3000 \mathrm{Ci} / \mathrm{mmol}$, New England Nuclear, Boston, MA, USA) by random primed labelling kit (Boehringer-Mannheim, Mannheim, West Germany). The radioactive probe was separated from unincorporated ${ }^{32} \mathrm{P}$-dCTP by gel filtration on a Sephadex G-50 column-preequilibrated with buffer (150 mM-sodium chloride, $10 \mathrm{~mm}$-Tris- $\mathrm{HCl}$, and $1 \mathrm{~mm}$-EDTA, $\mathrm{pH} 8.0)$. The specific activity of the ${ }^{32} \mathrm{P}$-labelled prolactin cDNA probe was $1-5 \times 10^{8} \mathrm{c} . \mathrm{p} . \mathrm{m} . / \mu \mathrm{g}$.

Northern blot hybridization procedure. Samples of total RNA (15 $\mu \mathrm{g})$ were denatured with $4 \mathrm{M}$-glyoxal, heated at $60^{\circ} \mathrm{C}$ for $30 \mathrm{~min}$ and subjected to electrophoresis in $0.9 \%$ agarose gels and blotted on Gene Screen filters (DuPont Ltd, Southampton, UK) in $10 \times \mathrm{SSC}(1.5 \mathrm{~m}$-sodium chloride, $150 \mathrm{~mm}$-sodium citrate, $\mathrm{pH} 7.0)$ using standard techniques (Maniatis et al., 1982). The filters were air dried and prehybrized in buffer $(900 \mathrm{~mm}-\mathrm{NaCl}, 5 \mathrm{~mm}-\mathrm{EDTA}$ and $50 \mathrm{~mm}$ sodium phosphate, $\mathrm{pH} 7 \cdot 7$, containing $50 \%$ formamide, $0.1 \%$ sodium dodecyl sulphate (SDS), $5 \times$ concentrated Denhardt's solution and denatured salmon sperm DNA $(200 \mu \mathrm{g} / \mathrm{ml})$ at $42^{\circ} \mathrm{C}$ for $3 \mathrm{~h}$. Radioactive cDNA probes were heated $\left(10 \mathrm{~min}, 100^{\circ} \mathrm{C}\right)$ immediately cooled on ice, added to the prehybridization soiution at a concentration of about $10 \mathrm{ng} / \mathrm{ml}$, and then hybridized for a further $22 \mathrm{~h}$ at $42^{\circ} \mathrm{C}$. The filters were washed in $2 \times \mathrm{SSC}$ and $0.1 \%$ SDS for $1 \mathrm{~h}$ at $65^{\circ} \mathrm{C}$. Washed filters were exposed to $\mathrm{X}$-ray film with intensifying screens, at $-70^{\circ} \mathrm{C}$.

RNA dot-blot hybridization assay. For dot blot analysis, total RNA was extracted as described above from the anterior pituitary, denatured $\left(60^{\circ} \mathrm{C}, 15 \mathrm{~min}\right)$ in $2 \times \mathrm{SSC}$ containing $4 \mathrm{M}$-glyoxal, and applied to Gene Screen filters using a dot manifold according to the instruction of the manufacturer (Bethesda Research Laboratory, Gathersburg, MD, USA). Hybridization conditions were identical to those used in the northern blot hybridization. Measurements of specific mRNA levels were determined on at least 4 dilutions of total RNA from individual pituitaries. The intensity of the ${ }^{32}$ P-DNA-RNA hybridization was quantitated by scanning radioactivity of the Gene Screen filters using the AMBIS Radioanalytic Image System (AMBIS Radioanalytic Image System, Inc., San Diego, CA, USA) and the amount of prolactin mRNA was expressed in c.p.m./4 $\mu \mathrm{g}$ total RNA. 
RIA and analyses of results. The plasma prolactin concentration and pituitary prolactin content were determined as previously described (Zadworny et al., 1988). Minimum detectable concentrations of prolactin for plasma and pituitary gland are $1 \mathrm{ng} / \mathrm{ml}$ and $10 \mathrm{ng} / \mathrm{mg}$, respectively. Samples were assayed for prolactin in a single assay to eliminate interassay variation. The intra-assay coefficient of variation for prolactin were $9 \cdot 2 \%$. Data were analysed by analysis of variance and Neuman-Keuls multiple Range Test.

\section{Results}

\section{Detection and characterization of prolactin mRNA in anterior pituitary}

A sample autoradiograph of a northern blot of chicken prolactin mRNA is shown in Fig. 1. A single, distinct species of $1.38 \mathrm{~kb}$ prolactin mRNA was detected in northern blots of total RNA isolated from the pituitaries of non-incubating Gifujidori bantam hens (Fig. 1, left lane). Very large amounts of $1.38 \mathrm{~kb}$ messages were observed in total RNA from incubating hens (Fig. 1, right lane). No prolactin mRNA was detected in total RNA from chicken liver or hypothalamus (data not shown). Although longer exposure (for 2 days) of the autoradiograph revealed the presence of larger molecular weight mRNA species $(3.7 \mathrm{~kb})$, it was much less abundant or negligible in comparison to the amount of $1.38 \mathrm{~kb}$ mRNA (data not shown).

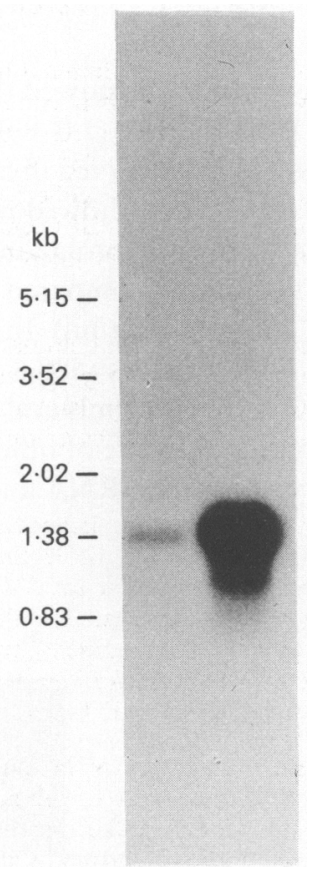

Fig. 1. Autoradiograph of northern blot showing determination of size of prolactin mRNA of non-incubating (left) and incubating (right) bantam hens. Fifteen $\mu \mathrm{g}$ of total RNA was applied in each lane. Numbers at left indicate molecular marker sizes in $\mathrm{kb}$. Exposure was for $3 \mathrm{~h}$.

Effects of photostimulation and incubation on prolactin mRNA and prolactin concentration in the anterior pituitary gland and on plasma concentration of prolactin

The out-of-lay bantam hens had regressed ovaries before photostimulation but gained body weight and ovary weight significantly increased 26 days after long-day exposure (Table 1; $P<0.05$ ). Three of the 5 photostimulated hens were actively laying eggs. Two other hens showed 
ovaries with atrophied follicles. About 40 days after the onset of photostimulation 3 hens laid eggs, subsequently began incubating eggs and sat on the nest for about 7 days. Body weight and ovary weight of these incubating hens significantly decreased, whereas total RNA in the pituitary gland of the incubating hens significantly increased when compared to those of the post-photostimulation group, respectively $(P<0.05)$.

Table 1. Body weight, ovary weight, pituitary weight and amount of total RNA in hens under different conditions

\begin{tabular}{lccc}
\hline & $\begin{array}{c}\text { Before } \\
\text { photostimulation }\end{array}$ & $\begin{array}{c}\text { After } \\
\text { photostimulation }\end{array}$ & Incubating \\
\hline Body weight $(\mathrm{g})$ & $698 \cdot 00 \pm 29 \cdot 00^{\mathrm{a}}$ & $960 \cdot 00 \pm 30 \cdot 0^{\mathrm{b}}$ & $803 \cdot 00 \pm 26 \cdot 0^{\mathrm{c}}$ \\
Ovary weight $(\mathrm{g})$ & $0 \cdot 63 \pm 0 \cdot 09^{\mathrm{a}}$ & $17 \cdot 43 \pm 8 \cdot 1^{\mathrm{b}}$ & $2 \cdot 47 \pm 0 \cdot 2^{\mathrm{a}}$ \\
Pituitary weight $(\mathrm{mg})$ & $4 \cdot 50 \pm 0 \cdot 50$ & $6 \cdot 00 \pm 0 \cdot 9$ & $7 \cdot 80 \pm 1 \cdot 3$ \\
Pituitary total & & & \\
$\quad$ RNA $(\mu \mathrm{g} / \mathrm{gland})$ & $12 \cdot 90 \pm 2 \cdot 40^{\mathrm{a}}$ & $14 \cdot 90 \pm 3 \cdot 1^{\mathrm{a}}$ & $28.40 \pm 5 \cdot 1^{\mathrm{b}}$ \\
\hline
\end{tabular}

Different superscripts indicate a statistically significant difference $(P<0 \cdot 05)$.

Values are means \pm s.e.m. for 3-5 hens.

An autoradiograph of a dot-blot hybridization showed that the hybridization signal was linear over the range of dilutions of pituitary RNA applied $(1 \cdot 0-8 \cdot 0 \mu \mathrm{g} / \mathrm{dot})$. The lowest concentrations of prolactin mRNA (c.p.m./4 $\mu$ g total RNA) were observed in hens of the pre-photostimulation group (Fig. 2). Hens of the post-photostimulation group showed no significant increase in pituitary prolactin mRNA or pituitary prolactin and plasma prolactin concentrations $(133.5 \pm 41.0$ c.p.m., $2.24 \pm 0.49 \mu \mathrm{g} / \mathrm{mg}, 165.3 \pm 100.6 \mathrm{ng} / \mathrm{ml}$ ) when compared to the pre-photostimulation group $(61.6 \pm 4.8$ c.p.m., $0.97 \pm 0.22 \mu \mathrm{g} / \mathrm{mg}, 23.8 \pm 7.4 \mathrm{ng} / \mathrm{ml})$. In contrast, the incubating hen showed a marked increase in pituitary prolactin mRNA levels (580.8 \pm 58.4 c.p.m.) and the concentrations of prolactin in the pituitary gland $(20.35 \pm 2.39 \mu \mathrm{g} / \mathrm{ml})$ and the plasma $(945.3 \pm 73.3 \mathrm{ng} / \mathrm{ml})$. The 10 -fold increase was significantly different from those of other groups $(P<0.01)$. There was a high correlation $(r=0.81)$ between pituitary prolactin mRNA and pituitary prolactin concentrations in hens used in the experiment.
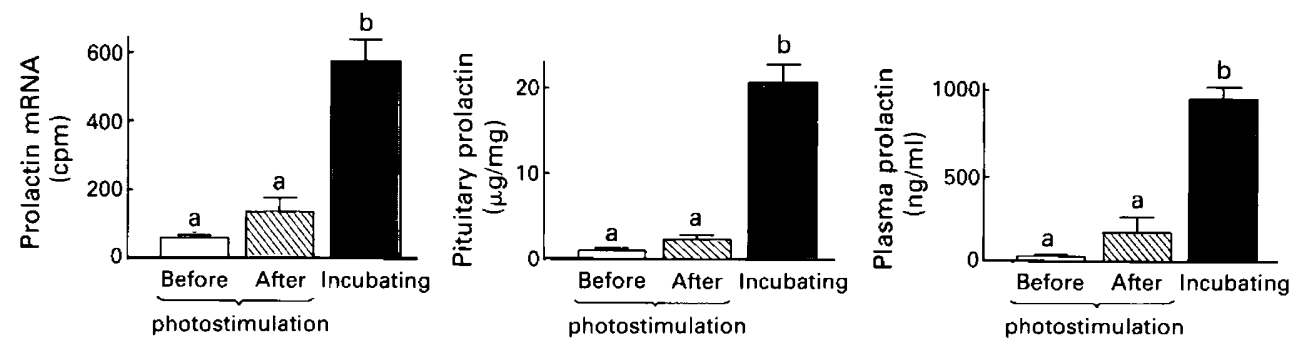

Fig. 2. Amount of pituitary prolactin mRNA, pituitary and plasma prolactin concentrations in hens in different states. Values are mean \pm s.e.m. for $3-5$ hens. Different superscripts indicate significant difference $(P<0.05)$.

\section{Effects of TRH on prolactin mRNA and prolactin concentrations in anterior pituitary and plasma}

Body weight, ovary weight, pituitary weight and yield of total RNA from the pituitary gland after 4 days of injections of saline or TRH are shown in Table 2. All the hens in every group had 
large yellow follicles and they were about to resume laying. Effects of TRH injections on quantity of prolactin mRNA and prolactin in the pituitary gland and prolactin concentrations in plasma are shown in Fig. 3. Injection of $0.25 \mu \mathrm{g} \mathrm{TRH} / \mathrm{kg}$ did not result in any changes in the variables measured $(P>0.05)$, whereas injections of a larger dose TRH $(2.5 \mu \mathrm{g} / \mathrm{kg})$ resulted in a significant increase in pituitary prolactin mRNA $(220.1 \pm 42.8$ c.p.m.; $P<0.05$; Fig. 3a). At the latter dose level there were no significant differences in the concentrations of prolactin in the pituitary gland $(6.34 \pm 2.32 \mu \mathrm{g} / \mathrm{mg})$ or plasma $(74.1 \pm 51.5 \mathrm{ng} / \mathrm{ml})$ when compared to the saline group (Fig. $3 \mathrm{~b}$; $102.1 \pm 37.2$ c.p.m., $4.01 \pm 0.91 \mu \mathrm{g} / \mathrm{mg}, 18.9 \pm 3.34 \mathrm{ng} / \mathrm{ml}$ ). There was no significant correlation between ovary weight, pituitary weight and the amount of prolactin mRNA in all the hens. Northern blot analysis revealed that only $1.38 \mathrm{~kb}$ RNA species characteristic of bantam hens (Fig. 1) was detected in all treatment groups (data not shown).

Table 2. Effects of TRH injections on body weight, ovary weight, and pituitary weight of photostimulated pre-laying hens

\begin{tabular}{|c|c|c|c|}
\hline & Saline & $\begin{array}{c}\text { TRH } \\
(0.25 \mu \mathrm{g} / \mathrm{kg})\end{array}$ & $\begin{array}{c}\text { TRH } \\
(2.5 \mu \mathrm{g} / \mathrm{kg})\end{array}$ \\
\hline Body weight (g) & $958.0 \pm 19.0$ & $908 \cdot 0 \pm 27 \cdot 0$ & $884.0 \pm 9.0$ \\
\hline Ovary weight (g) & $22 \cdot 7 \pm 5 \cdot 3$ & $14 \cdot 4 \pm 5 \cdot 5$ & $27 \cdot 6 \pm 1 \cdot 3$ \\
\hline Pituitary weight (mg) & $6.1 \pm 0.5$ & $4 \cdot 7 \pm 0 \cdot 4$ & $6 \cdot 0 \pm 0.7$ \\
\hline \multicolumn{4}{|l|}{ Pituitary total } \\
\hline RNA ( $\mu \mathrm{g} /$ gland $)$ & $19.8 \pm 1.4$ & $19.5 \pm 1.7$ & $22 \cdot 3 \pm 1.7$ \\
\hline
\end{tabular}

Values are means \pm s.e.m. for 5 hens.
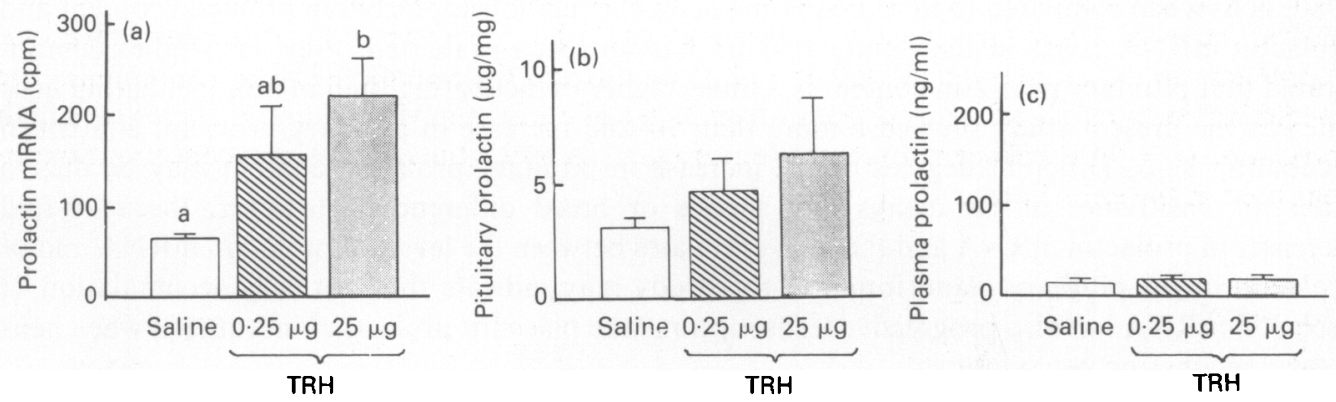

Fig. 3. Amount of pituitary prolactin mRNA, pituitary and plasma prolactin concentrations in out-of-lay hens treated with TRH. Values are mean \pm s.e.m. for 5 hens/group. Different superscripts indicate significant difference $(P<0.05)$.

\section{Discussion}

The present study not only confirms the presence of prolactin mRNA in the pituitary gland of bantam hens (Hanks et al., 1989) but also demonstrates conspicuous changes in prolactin gene expression in relation to prolactin production in the anterior pituitary of hens in different physiological states. Although the previous study reported that $0.88 \mathrm{~kb}$ prolactin mRNA is the major molecular weight species of mRNA (1.7-6.2 kb nuclear intermediary transcripts), the present study showed that a larger size of prolactin mRNA $(1.38 \mathrm{~kb})$ is the major molecular weight species. 
Although the autoradiograph of a northern blot (Fig. 1, right lane) shows a large amount of prolactin mRNA ranging from 1.5 to $0.9 \mathrm{~kb}$ in the incubating hens, the scanning analysis of the radioactivity displayed only a single molecular species at $1.38 \mathrm{~kb}$. This mRNA may be the final transcript rather than an intermediary transcript processed to the $0.88 \mathrm{~kb}$ mRNA in the anterior pituitary of the Gifujidori bantam hens. At present, the reason for this discrepancy remains unknown but it may not be attributable to different amounts and species of RNAs ( $4 \mu \mathrm{g}$ of pituitary poly(A) RNA in the previous study and $15 \mu \mathrm{g}$ of total RNA in this study) or different lengths of the cDNA probes used ( $850 \mathrm{bp}$ in the previous study and $270 \mathrm{bp}$ in this study). In support of this possibility, using the same procedure as described here, we have detected a $0.88 \mathrm{~kb}$ prolactin mRNA as the major molecular weight species in the pituitary gland of single-comb White Leghorn hens actively laying but rarely showing maternal behaviour of broodiness. The various sizes of $\mathrm{mRNA}$ detected in the different breeds of chickens may reflect different lengths of untranslated regions at the $5^{\prime}$ or $3^{\prime}$ ends of the transcript (Hanks et al., 1989; Watahiki et al., 1989) or may arise from differences in use of alternative polyadenylation sites (Karatzas et al., 1990). It is unlikely that the coding regions are substantially different in size since prolactin cDNA from broiler chickens (Watahiki et al., 1989) and from bantam chickens (Hanks et al., 1989) were the same as has been reported for other avian species (turkey: Karatzas et al., 1990). Direct evidence for either possibility awaits nucleotide information from different mRNAs. Monomeric turkey prolactin exists in 3 isohormone forms, one of molecular weight 22000 and the other two about 26500 (Proudman \& Corcoran, 1981; J. A. Proudman, personal communication). We have demonstrated that mRNA isolated from the anterior pituitary glands of crossbred broiler chicken synthesizes proteins in vitro of molecular weight 27000 and 27500 which are immunoprecipitated with turkey prolactin antibody but only the smaller protein $M_{\mathrm{r}} 27000$ ) is immunodisplaceable (Shimada et al., 1989). It is unclear whether the chicken pituitary gland synthesizes different forms of prolactin as does the turkey.

Although previous reports have shown a larger amount of prolactin in the pituitary gland of incubating chicken (Saeki \& Tanabe, 1955) and turkey (Cherms et al., 1962; Burke \& Papkoff, 1980) hens when compared to non-incubating hens, the relationship between prolactin content and prolactin mRNA levels in the pituitary gland has not been evaluated. Previous studies demonstrated that pituitary prolactin content is 3 times higher in incubating than in non-incubating hens whereas the present study showed a more than 10 -fold increase in pituitary prolactin content in incubating hens. Different degrees of the increase in pituitary prolactin content may be due to different sensitivities of the assays and species or breed differences. However, the $>10$-fold increases in prolactin mRNA and the high correlates between the levels of prolactin mRNA and of prolactin in the pituitary gland found in this study may indicate that not only accumulation of prolactin mRNA but also progressive transcription take place for prolactin biosynthesis when hens display incubation behaviour.

The mechanisms of regulation of prolactin gene expression remain unknown in birds. TRH can induce prolactin release in the chicken anterior pituitary in vitro (Hall et al., 1975; Harvey et al., 1978), whereas in-vivo administration of TRH failed to induce a release in the young chicken (Harvey et al., 1978), as was observed in the present study. The latter results do not necessarily mean little effect of TRH on protein synthesis. In fact, the present study suggests that TRH may contribute to the transcriptional regulation of prolactin mRNA when it is injected at a high dose but that not all mRNA is being efficiently translated into the protein after TRH treatment. It has been claimed that the rat fetus is not capable of producing a large amount of prolactin, probably due to insufficient production of ribosomal RNA, although a large amount of prolactin mRNA is produced (Frawley \& Miller, 1989). Whether possible cessation of translational process leading to prolactin synthesis in the chicken is attributable to less availability of ribosomal RNA or other factors needs further investigation. To study the relative contributions of transcriptional control on the observed stimulation of prolactin gene expression by TRH in the chicken, the transcriptional rate of the prolactin gene, as measured by nuclear run-off assays, should be compared with the effects on prolactin mRNA levels. These studies have not yet been undertaken. 
We thank Dr J. A. Proudman (USDA, Beltsville, MD) for turkey prolactin; Dr W. H. Burke (University of Georgia, Athens, GA) for turkey prolactin antibody; Dr K. Nakashima (University of Mie, TSU, Japan) for DNA fragment of chicken prolactin; Radioisotope Centre of Nagoya University for use of The AMBIS Radioanalytic Image System; and Dr D. Zadworny for commenting on the manuscript. This work was supported in part by the Ishida Foundation and a grant-in-aid from the Ministry of Education of Japan (No. 02304027) to K.S.

\section{References}

Burke, W.H. \& Dennison, P.T. (1980) Prolactin and luteinizing hormone levels in female turkeys (Meleagris gallopavo) during a photoinduced reproductive cycle and broodiness. Gen. comp. Endocrinol. 41, 92-100.

Burke, W.H. \& Papkoff, H. (1980) Purification of turkey prolactin and the development of a homologous radioimmunoassay for its measurement. Gen. comp. Endocrinol. 40, 297-307.

Cherms, F.L., Herrick, P.B., McShan, W.H. \& Hymer, W.C. (1962) Prolactin content of the anterior pituitary gland of turkey hens in different reproductive stages. Endocrinology 71, 288-292.

Chomczynski, P. \& Sacchi, N. (1987) Single-step method of RNA isolation by acid guanidinium thiocyanatephenol-chloroform extraction. Analyt. Biochem. 162, 156-159.

Fehrer, S.C., Silsby, J.L, Behnke, E.J. \& El Halawani, M.E. (1985) The influence of thyrotropin releasing hormone on in vivo prolactin release and in vitro prolactin, luteinizing hormone, and growth hormone release from dispersed pituitary cells of the young turkey (Meleagris gallopavo). Gen. comp. Endocrinol. $59,64-72$.

Frawley, L.S. \& Miller, H.A., III (1989) Ontogeny of prolactin secretion in the neonatal rat is regulated postranscriptionally. Endocrinology 124, 3-6.

Hall, T.R., Chadwick, A., Bolton, N.J. \& Scanes, C.G. (1975) Prolactin release in vitro and in vivo in the pigeon and the domestic fowl following administration of synthetic thyrotropin-releasing factor. Gen. comp. Endocrinol. 25, 298-306.

Hanks, M.R., Alonzi, J.A., Sharp, P.J. \& Sang, H.M. (1989) Molecular cloning and sequence analysis of putative chicken prolactin cDNA. J. molec. Endocrinol. 2, 21-30.

Harvey, S., Bedrak, E. \& Chadwick, A. (1981) Serum concentrations of prolactin, luteinizing hormone, growth hormone, corticosterone, progesterone, testosterone and oestradiol in relation to broodiness in domestic turkeys (Meleagris gallopavo). J. Endocr. 89, 187-95.

Harvey, S., Scanes, C.G., Chadwick, A. \& Bolton, J.J. (1978) The effect of thyrotropin-releasing hormone (TRH) and somatostain (GHRIH) on growth hormone and prolactin secretion in vitro and in vivo in the domestic fowl (Gallus domesticus). Neuroendocrinology 26, 249-260.

Karatzas, K., Zadworny, D. \& Kuhnlein, U. (1990) Nucleotide sequence of turkey prolactin. Nucl. Acids Res. 18, 3071.

Kono, T., Kuwayama, T., Itoh, H. \& Ichinoe, K. (1985) Nesting behaviour and changes in plasma concen- trations of progesterone, testosterone and estradiol in the native Japanese breed of chicken Gifujidori (Gallus domesticus). Japan. Poult. Sci. 22, 64-72.

Laveriere, J.-N., Tixier-Vidal, A., Buisson, N., Morin, A., Martial, J.A. \& Gourdji, D. (1988) Preferential role of calcium in the regulation of prolactin gene transcription by thyrotropin-releasing hormone in $\mathrm{GH} 3$ pituitary cells. Endocrinology 122, 333-340.

Maniatis, T., Fritsch, E.F. \& Sambrook, J. (1982) Molecular Cloning: a Laboratory Manual. Cold Spring Harbor.

Maurer, A. (1982) Estradiol regulates the transcription of the prolactin gene. J. biol. Chem. 257, 2133-2136.

Murdock, G.H., Waterman, M., Evans, R.M. \& Rosenfeld, M.G. (1985) Molecular mechanisms of phorbol ester, thyrotropin-releasing hormone, and growth factor stimulation of prolactin gene transcription. $J$. biol. Chem. 260, 11852-11858.

Proudman, J.A. \& Corcoran, D.H. (1981) Turkey prolactin: purification by isotachophoresis and partial characterization. Biol. Reprod. 25, 375-384.

Proudman, J.A. \& Opel, H. (1981) Turkey prolactin: validation of a radioimmunoassay and measurement of changes associated with broodiness. Biol. Reprod. 25, 573-580.

Riddle, O., Bates, R.W. \& Lahr, E.L. (1935) Prolactin induces broodiness in fowl, Am. J. Physiol. 111, $352-360$.

Saeki, Y. \& Tsanabe, Y. (1955) Changes in prolactin content of fowl pituitary during broody periods and some experiments on the induction of broodiness. Poultry Sci. 34, 909.918.

Seo, H. (1989) Prolactin gene expression ... an overview. In Kyoto Prolactin Conference Monograph, Vol. 4, pp. 78-95. Ed. K. Hoshino. Kyoto University, Kyoto.

Sharp, P.J., Scanes, C.G., Williams, J.B., Harvey, S. \& Chadwick, A. (1979) Variations in concentrations of prolactin, luteinizing hormone, growth hormone and progesterone in the plasma of broody bantams (Gallus domesticus). J. Endocr. 80, 51-57.

Sharp, P.J., Macnamee, M.C., Sterling, R.J., Lea, R.W. \& Pedersen, H.C. (1988) Relationship between prolactin, $\mathrm{LH}$ and broody behaviour in bantam hens. $J$. Endocr. 118, 279-286.

Shimada, K., Zadworny, D., Ishida, H., Sato, K., Seo, H., Murato, Y. \& Matsui, N. (1989) Studies on the cloning and molecular characterization of the chicken prolactin gene. In Kyoto Prolactin Conference Monograph, Vol 4, pp. 105-114. Ed. K. Hoshino. Kyoto University, Kyoto.

Watahiki, M., Tanaka, M., Masuda, N., Sugisaki, K., Yamamoto, M., Yamakawa, M., Nagai, J. \& 
Nakashima, K. (1989) Primary structure of chicken pituitary prolactin deduced from the cDNA sequence. Conserved and specific amino acid residues in the domains of the prolactins. J. biol. Chem. 264, 5535-5539.

Yamamoto, N., Seo, H., Suganuma, N., Nakane, T., Kuwayama, A. \& Kageyama, N. (1986) Effect of estrogen on prolactin mRNA in the rat pituitary. Neuroendocrinology 42, 494-497.

Zadworny, D., Walton, J.S. \& Etches, R.J. (1985) The relationship between plasma concentrations of prolactin and consumption of feed and water during the reproductive cycle of the domestic turkey. Poultry Sci. 64, 401-410.
Zadworny, D., Shimada, K., Ishida, H., Sumi, C. \& Sato, K. (1988) Changes in plasma levels of prolactin and estradiol, nutrient intake and time spent nesting during the incubation phase of broodiness in the Chabo hen (Japanese bantam). Gen. comp. Endocrinol. 71, 406-412.

Zadworny, D., Shimada, K., Ishida, H. \& Sato, K. (1989) Gonadotropin-stimulated estradiol production in small ovarian follicles of the hen is suppressed by physiological concentrations of prolactin in vitro. Gen. comp. Endocrinol. 74, 468-473.

Received 30 March 1990 